\title{
Recent Research on the Archaeological and Historical Evidence of the Hasanai
}

Paul S. Marceaux

Unknown

Follow this and additional works at: https://scholarworks.sfasu.edu/ita

Part of the American Material Culture Commons, Archaeological Anthropology Commons, Environmental Studies Commons, Other American Studies Commons, Other Arts and Humanities Commons, Other History of Art, Architecture, and Archaeology Commons, and the United States History Commons

Tell us how this article helped you.

This Article is brought to you for free and open access by the Center for Regional Heritage Research at SFA ScholarWorks. It has been accepted for inclusion in Index of Texas Archaeology: Open Access Gray Literature from the Lone Star State by an authorized editor of SFA ScholarWorks. For more information, please contact cdsscholarworks@sfasu.edu. 


\section{Recent Research on the Archaeological and Historical Evidence of the Hasanai}

Creative Commons License

(c) (i) (8)

This work is licensed under a Creative Commons Attribution-NonCommercial 4.0 International License 


\title{
RECENT RESEARCH ON THE ARCHAEOLOGICAL AND HISTORICAL EVIDENCE OF THE HASINAI
}

\author{
Paul Shawn Marceaux
}

\section{Introduction}

This article was assembled using information collected for my dissertation proposal. The Allen Phase Caddo sites and other aboriginal Historic sites of interest are located in the upper Neches and Angelina River basins in East Texas, and were identified from various sources in the archaeological literature . In addition, regional archaeologists and avocational archaeologists, including several participants of the East Texas Caddo Research Group 2006 meeting, provided information and helped in the process of vetting sites.

My dissertation will examine the archival and archaeological records in hopes of identifying the archaeological correlates of Hasinai Caddo groups in East Texas. To accomplish this I will revisit primary documents and their translations, analyze known archaeological site collections, and locate, document, analyze and, if possible, contextualize unreported private collections. Utilizing multiple lines of evidence, including a broad survey of sites (Figure 1), collections, and a detailed examination of regional ceramic attributes, I propose to link archaeological sites to specific Hasinai regional entities.

Native Caddo groups inhabited the area between the Neches and Angelina river valleys of East Texas for hundreds of years before the first European contact at ca. A.D. 1542. Written accounts from the time of sustained contact, more than 100 years later have informed and influenced our understanding of the social, political, and economic organization of the Caddo. Over the last half-century many public and privately owned archaeological sites have been excavated and reported, but to my knowledge there has not been a detailed region-wide ceramic study of archaeological sites and collections from the upper Neches and Angelina river drainages.

\section{The Hasinai in the Archaeological and Historic Record}

The Hasinai confederacy ${ }^{1}$, comprised of sedentary Caddo groups living in dispersed settlements along the upper Neches and Angelina rivers, was united through the religious leadership of a grand xinesí (Perttula 1993, 2001). The hierarchical structure of the Hasinai is also evidenced by a set of hereditary and appointed officials, including caddices and canahas, who governed and mediated important matters. Ethnographic accounts from ca. 1690 (Casañas 1927; Espinosa 1927; Foster 1998; Hidalgo 1927; Joutel 1906; Margy 1879), although not exact in terms of location, provide evidence as to the position and geographical extent of some of the Caddo groups. The Frenchman René

\footnotetext{
${ }^{1}$ Anthropologists and archaeologists have used the term 'confederacy', although it does not appear in the historical sources.
} 


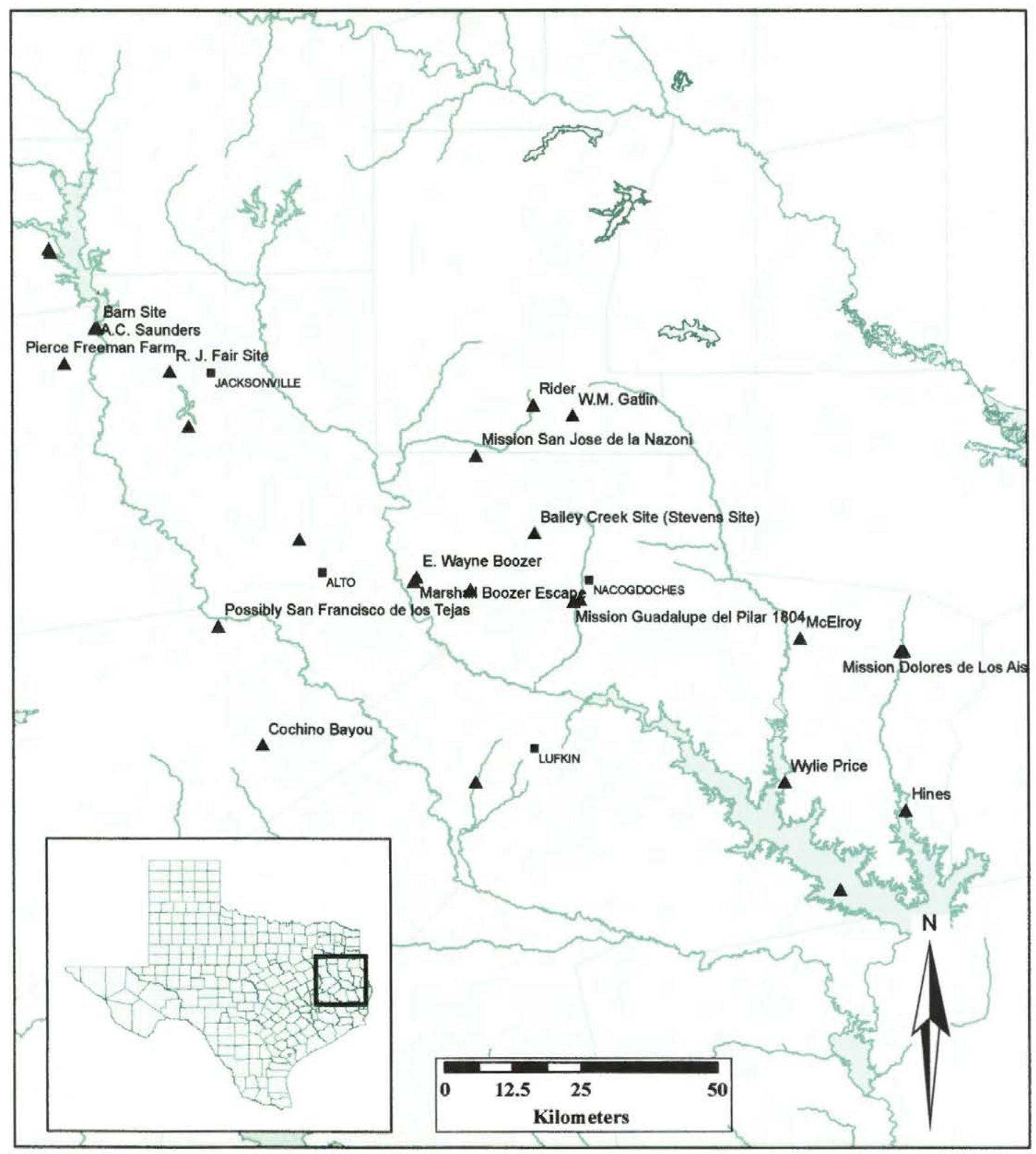

Figure 1. Historic and potentially historic sites of interest. 
Robert Cavelier, Sieur de La Salle visited the Cenis [Hasinai] in 1686, and Henri Joutel, with survivors from the failed Fort St. Louis, spent two months among the Nabedache and lower Nasoni the following year. Over the last two decades archaeologists have identified sites associated with these two groups of the Hasinai confederacy (Bill Young, personal communication 2006; Corbin 1989:273; Kenmotsu and Perttula 1993:151; Perttula and Nelson 2006).

Perttula and Nelson (2006) recently excavated two sites in Mission Tejas State Park, Houston County, which they determined to be part of the Nabedache village known from historical sources. The sites are possibly associated with either Mission San Francisco de los Tejas [1690] or with Mission Nuestro Padre San Francisco de Tejas [1716] or with both. In the late $17^{\text {th }}$ and early $18^{\text {th }}$ centuries there were six named Spanish missions cstablished in seven locations in East Texas (Figure 2). Mission San José de los Nasonis [1716] is one of only two positively identificd East Texas missions, thus making it an invaluable addition to the archaeological record. Mission Nasonis was locatcd in Rusk County in 1988 by Bill Young, a Texas Historical Commission Steward. According to Espinosa, Mission Nasonis is associated with the Nasoni Caddo group (Tous 1930:2324), as the name indicates, and although most East Texas Caddo archaeologists are aware of the site only limited investigations have taken place there, and none have been published.

Joutcl's diary [1685-1687] provides detailed descriptions of French interaction with the Cenis [Hasinai] groups, but it would be several years before the Spanish established permanent settlements in the area. In 1691, we learn of the affiliation of the nine nations occupying the Hasinai province. The Franciscan Fray Francisco Casañas de Jesús María (169l) listed the Aseney [Hasinai] as consisting of the Nabadacho [Nabedache], Necha, Nechavi, Nacono, Nacachau, Nazadachotzi, Cachaé, Nabiti, and Nasayaha. Casañas further noted that the nine affiliated groups were "agreeable and obedient to the demands of the grand xinesi, who is like a small king" (my translation of Casañas 1691). The Nazonis [Nasoni], along with many other groups, are listed as tribes friendly to the province of the Hasinai but not necessarily subject to the grand xinesí.

It is not until after 1716 that several groups, including the Nasoni, Nadaco, and Nacaos, are included in lists of the Hasinai confederacy. Based on historical sources, arehaeologists have noted that the leadership around this time was "a governing elite consisting of a religious head (xinesi) and village or confederacy assemblies" (Wyckoff and Baugh 1980:238). Perttula notes (1992:177) that when comparing ethnographically recorded locations of the affiliated Hasinai groups to the archaeological data available from the Neches and Angelina drainages two points are apparent:

First, that fairly specific Caddoan cthnic affiliations may be feasible for the Allen phase components in proximity to El Caminos Reales (Corbin 1991) and, second, that Allen phase components in the upper Neches River basin cannot be presently affiliated with any known Caddoan group, "band," or tribe. 


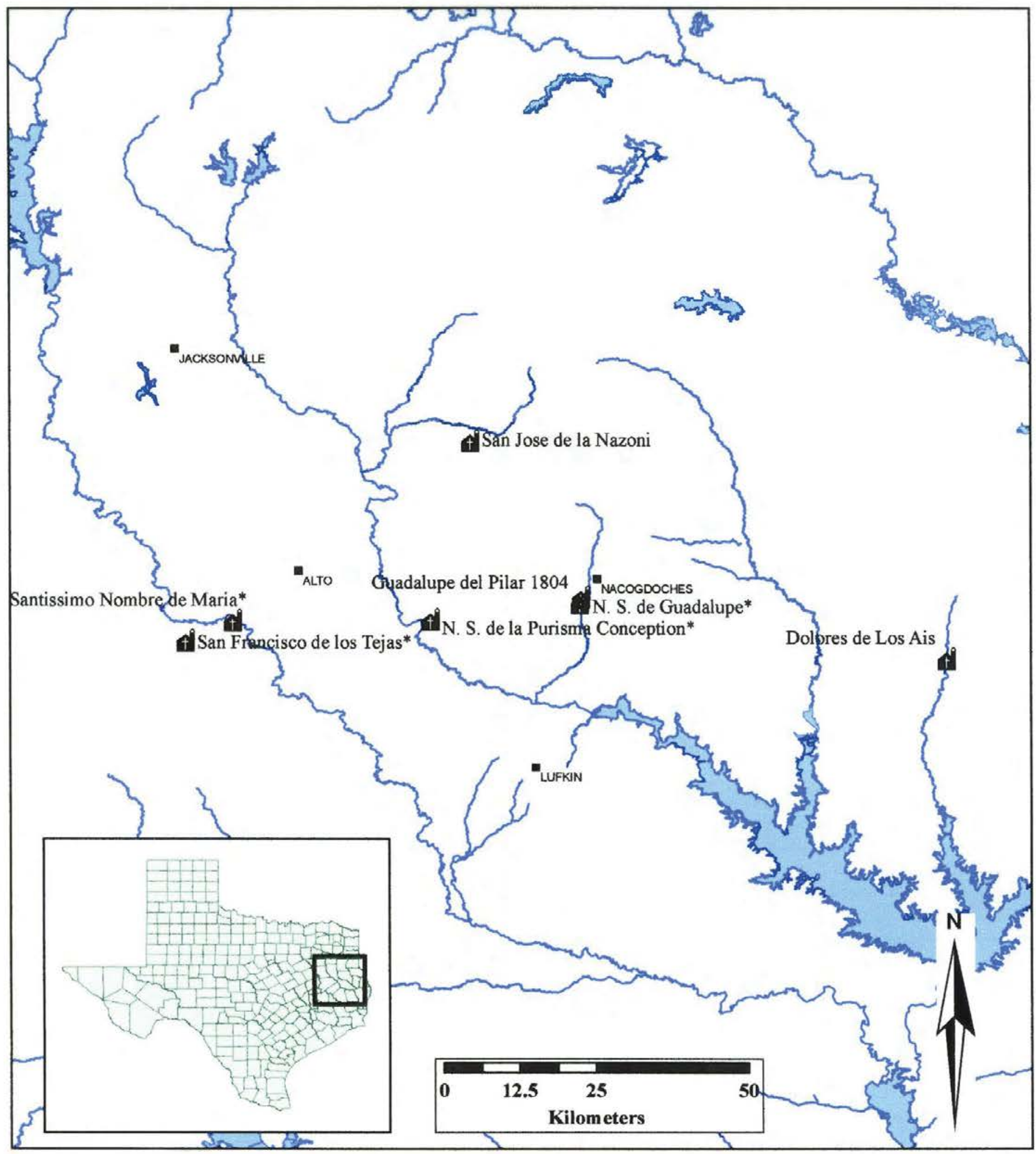

* indicates the exact location is unknown

Figure 2. Spanish missions in the upper Neches and Angelina River valleys. 
There are several important surveys of Historic Caddo Allen phase sites in the study area (Kenmotsu and Perttula 1993; Perttula 1992:115-117; Story 1982, 1990), but none examine the distribution of detailed regional ceramic attributes across these sites. This, along with new translations and the re-examination of primary sources, may provide new insight into the socio-political organization of the Hasinai Caddo groups.

\section{Other Previous Research}

Krieger's (1946:205-211) discussion of the Fulton Aspect notes that "the Frankston Focus was, in the main, a prehistoric culture" recognized as the Hasinai groups. He also identified the association between Patton Engraved ceramics and sites with European goods. In the later Introductory Handbook of Texas Archeology, Suhm et al. (1954:219-221) first characterize the Allen Focus ${ }^{2}$ (dating from ca. A.D. 1600-1800) as dominated by Patton Engraved ceramics, Cuney and Turney projectile points, and European trade goods. The distribution of Patton Engraved and other ceramic types associated with Allen phase sites (Figure 3), including Poynor Engraved, Hume Engraved, Bullard Brushed, Killough Pinched, LaRue Neck Banded, and Maydelle Incised (see Fields 1981; Kleinschmidt 1982; Shafer n.d.; Story and Creel 1982; Suhm and Jelks 1962), will provide an analytical tool that can be used to approximate the geographical extent of some Hasinai groups.

The most comprehensive archaeological research in the study area comes from the work at the Deshazo site in Nacogdoches County (Story 1982, 1995). Using this Allen phase site and their knowledge of the regional archaeology, Story and Creel (1982:32-34) suggest that the Late Prehistoric and Historic Caddo groups at times were organized socio-politically into constituent groups that comprised an affiliated group headed by the grand xinesí. This suggestion provides a testable model based on constituent groups, ethnographically analogous to the above mentioned nine principal historical tribes, whereby each constituent group would share a greater number and variety of elements of material culture than the affiliated group.

Drawing from a larger sample of sites and archaeological data, but utilizing local and regional ceramic studies (Campbell 1936; Cole 1975; Fields 1981; Gilmore 1973; Kleinschmidt 1982; Shafer n.d.; Story 1982, 1995), I propose to identify and refine the chronology of specific affiliated and constituent groups. Historic archives, ceramic styles and their variations, and inclusive material culture assemblages will be the basis for identifying differences from one area and group to another.

\footnotetext{
${ }^{2}$ The Allen Focus designation was changed to Allen phase (Story 1982) when the use of Aspect and Focus designations fell out of favor for the more general term phase. Herein, I will use Perttula and Nelson's (2006) dates for the Allen phase (A.D. 1650-1800).
} 


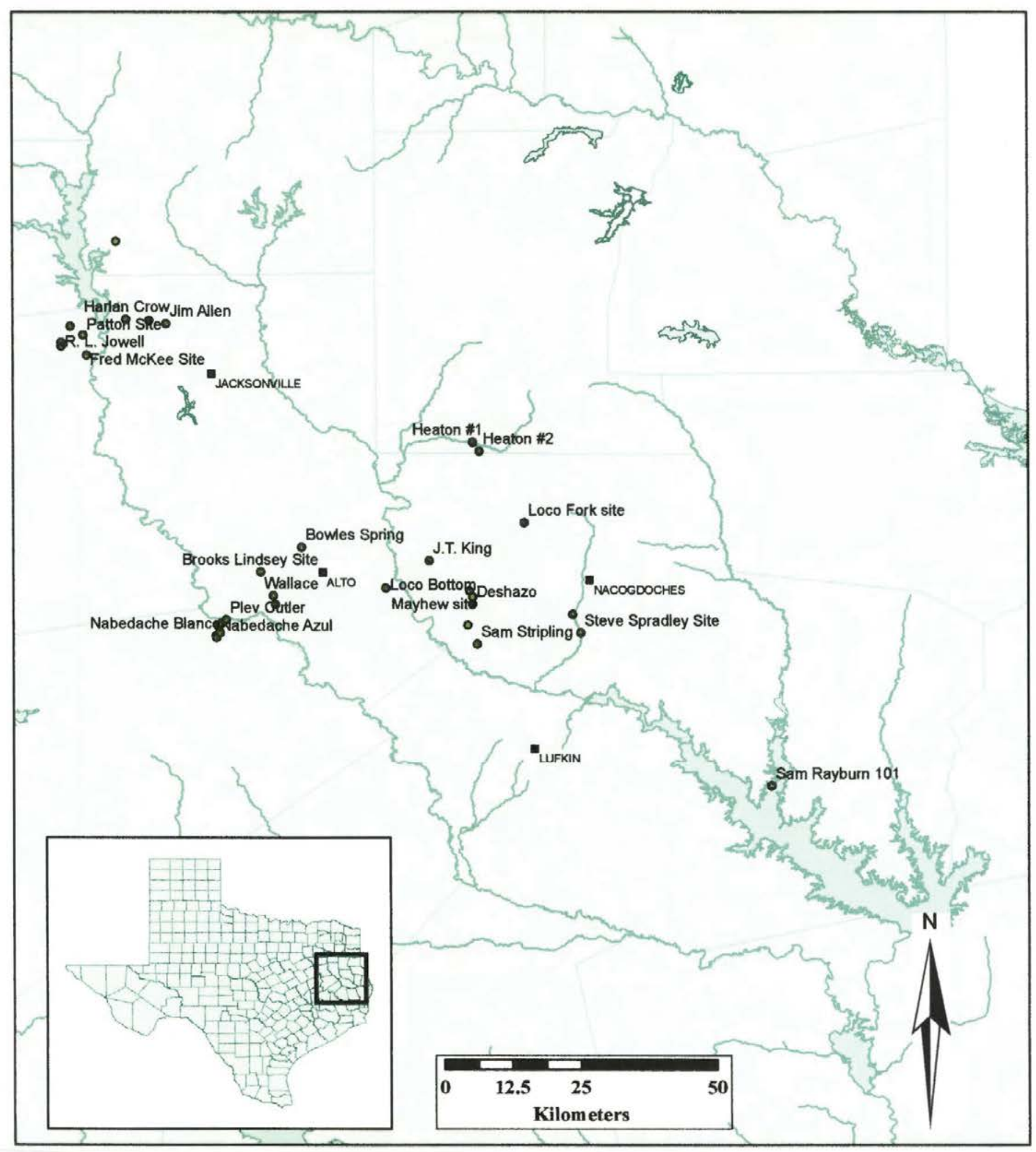

Figure 3. Allen phase sites 


\section{Methodology and Ceramic Analysis}

As mentioned above, there has not been a detailed region-wide ceramic study of archaeological sites and collections from the Neches and Angelina river drainages. In fact, according to Perttula (1992:78), "there has never been a comprehensive survey effort carried out within any part of the Caddo Area to acquire the regional archaeological data to characterize the density and distribution of Caddo sites that postdate 1520." To correct this problem and as the basis for my dissertation work I have created and developed a database containing site and locational data from over 800 Caddo sites, ranging in age from Early Caddo to the Historic period. Using the power of database queries and Geographic Information Systems (GIS) mapping, I have identified approximately 60 Caddo sites in the Neches and Angelina River drainages that date to the latter part of the Late Prehistoric and Historic periods. Over half of the sites contain both Caddo ceramics and European trade goods, confirming their historic context.

My research relies primarily on four sets of data: (1) unreported private collections of ceramic sherds, including those from Mission San José de los Nasonis and the Henry M site in Nacogdoches County, (2) existing ceramic collections consisting of vessels and sherds (including the most recently excavated sites) stored at regional facilities such as the Texas Archeological Research Laboratory in Austin and at Stephen F. Austin University in Nacogdoches, (3) regional site, artifact, and locational data gathered from previous reports and compiled in a database, and (4) early French and Spanish historical documents associated with this area.

The principal objective of the research is to determine how specific pottery attributes of morphology, technology, and style from the study area correlate with sites found in the presumed locations of the principal tribes of the Hasinai as indicated by the archaeological and historical records. In other words, how do ceramic assemblages from the region reflect the position and geographical extent of Hasinai groups? It is my belief that a survey of historic Caddo sites will provide a means of identifying these affiliated and constituent groups.

In all, 28 sites identified as having Historic period or potentially historic components (Table 1) of Caddo age, and 35 Allen phase sites (see Figure 3 and Table 2), are included in the analysis. Pottery attributes such as techniques of surface treatment, temper, decorative motif or element and, when possible, manufacturing technique, vessel part, and form will be recorded. Plain, brushed, and some ceramics decorated while the paste was wet, are thought to represent utilitarian wares and will be quantified using counts and weights. It has also been demonstrated that the plain to decorated sherd ratio decreases through time from Late Prehistoric to the Historic Caddo period (Perttula and Nelson 2006), providing a provisional chronological measure. 
Table 1. Historic and potentially historic sites in the study area.

\begin{tabular}{|c|c|c|}
\hline Site Trinomial & Site Name & Source \\
\hline 41AG22 & & K\&P*, Story 1990 \\
\hline 41AG39 & & K\&P, Story 1990 \\
\hline 4IAG57 & & TARL Dbase \\
\hline 41AN164 & Bam Site & TARL Dbase \\
\hline $41 \mathrm{CE} 333$ & & THC Sites Atlas \\
\hline 41HE139 & & TARL Dbase \\
\hline 41HE14 & & TARL Dbase \\
\hline $41 \mathrm{HO6}$ & Possibly San Francisco de los Tejas & K\&P, Story 1990 \\
\hline 41NA171 & & TARL Dbase \\
\hline 41NA202 & Bailey Creek Site (Stevens Site) & THC Sites Atlas, Tim Perttula (Personal Comm.) \\
\hline 41NA207 & & THC Sites Atlas \\
\hline 41NA208 & E. Wayne Boozer & THC Sites Atlas \\
\hline 41NA22 & & K\&P \\
\hline 41NA223 & Mission Church Guadalupe del Pilar 1804 & TARL Dbase \\
\hline 41RK1 & W.M. Gatlin & K\&P, Story 1990 \\
\hline 41RK5 & Rider & K\&P, Story 1990 \\
\hline 41RK200 & Mission San Jose de la Nazoni & K\&P, TARL Dbase \\
\hline 41SA116 & McElroy & K\&P, Story 1990, Jelks 1965 \\
\hline 41SA25 & Mission Dolores de Los Ais & THC Sites Atlas, Story 1990, Corbin et al 1980 \\
\hline $41 \mathrm{SA} 38$ & & K\&P, Story 1990 \\
\hline 41SA41 & & K\&P, Story 1990 \\
\hline 41SA94 & Wylie Price & K\&P, Story 1990, Jelks 1965 \\
\hline 41SA95 & Hines & K\&P, Story 1990, Stephenson 1950 \\
\hline \multicolumn{3}{|l|}{ Possibly include } \\
\hline 41AN19 & A.C. Saunders & Kleinschmidt 1982 \\
\hline 41AN34 & Pierce Freeman Farm & TARL Dbase \\
\hline 41CE25 & R. J. Fair Site & K\&P, TARL Dbase \\
\hline $41 \mathrm{CE} 45$ & & K\&P, TARL Dbase \\
\hline $41 \mathrm{HO} 212$ & & THC Sites Atlas \\
\hline
\end{tabular}

* Kenmotsu and Perttula 1993 
Table 2. Allen phase sites to be included in the study.

\begin{tabular}{|c|c|c|}
\hline Site Trinomial & Site Name & Source \\
\hline $41 \mathrm{AN} 13$ & R. L. Jowell & THC Sites Atlas, Cole 1975, Story 1990 \\
\hline 41AN21 & Mrs. Emma Owens Site & TARL Dbase, Story 1990, Cole 1975 \\
\hline 41AN26 & Patton Site & TARL Dbase, Story 1990, Cole 1975, Kleinschmidt 1982 \\
\hline 41AN32 & Fred McKee Site & TARL Dbase, Story 1990 , Cole 1975 \\
\hline 41AN8 & L. Cecil Farm I and II & TARL Dbase \\
\hline $41 \mathrm{CE} 12$ & Jim Allen & K\&P, Story 1990, Cole 1975, Kleinschmidt 1982 \\
\hline 41CE19 & George C. Davis Site & K\&P, Story, Newell and Krieger 1949 \\
\hline $41 C E 20$ & Wallace & TARL Dbase, Story 1990 \\
\hline 41CE293 & Brooks Lindsey Site & K\&P, TARL Dbase \\
\hline 41 CE354 & Harlan Crow & Tim Perttula, personal communication \\
\hline $41 \mathrm{CE} 48$ & Bowles Spring & K\&P, Story 1990 \\
\hline 41CE6 & E. W. Hackney & K\&P, Story 1990, Cole 1975, Kleinschmidt 1982 \\
\hline 41CE62 & & THC Sites Atlas \\
\hline $41 \mathrm{HO}$ & Plev Cutier & K\&P, Story 1990 \\
\hline $41 \mathrm{HO} 22$ & & Erickson and Corbin 1996 \\
\hline $41 \mathrm{HO} 147$ & & Erickson and Corbin 1996 \\
\hline $41 \mathrm{HO} 211$ & Nabedache Blanco & Perttula and Nelson 2006 \\
\hline $41 \mathrm{HO} 214$ & Nabedache Azul & Perttula and Nelson 2006 \\
\hline $41 \mathrm{HO} 64$ & G.A. Moore Site lb & K\&P, Story 1990 , Perttula 2005 \\
\hline $41 \mathrm{HO65}$ & G.A. Moore Site lc & K\&P, TARL Dbase, Story 1990, Perttula 2005 \\
\hline $41 \mathrm{HO} 67$ & Krieger's George A. Moore Site 3 & K\&P, Story 1990 \\
\hline $41 \mathrm{HO} 91$ & & Erickson and Corbin 1996 \\
\hline 41 NA113 & & K.\&P, Story 1990 \\
\hline 41NA15 & J.T. King & K\&P, Story 1990 \\
\hline 41 NA183 & Loco Fork & Tom Middlebrook (Personal communication) \\
\hline 41NA197 & Sam Stripling & TARL Dbase \\
\hline 41NA206 & Steve Spradley & Tom Middlebrook (Personal communication) \\
\hline 41NA21 & Mayhew site & K\&P, Story 1990, Kenmotsu 1992 \\
\hline 41NA27 & Deshazo & K\&P, TARL Dbase, Story 1982,1990 \\
\hline $41 \mathrm{NA} 60$ & Henry Mast, Loco Bayou \#104 & K\&P, TARL Dbase \\
\hline 41NA67 & Sam Rayburn 101 & K\&P, TARL Dbase, Story 1990 \\
\hline 41RK191 & & K\&P, TARL Dbase \\
\hline 41RK197 & & $\mathrm{K} \& \mathrm{P}$ \\
\hline $41 \mathrm{SM} 77$ & Vanderpool & Tim Perttula (Personal communication) \\
\hline
\end{tabular}




\section{Conclusions}

I will employ a multifaceted approach that utilizes unpublished archaeological investigations, information on material culture from previous, current, and ongoing regional studies, and archival records documenting the arrival and subsequent occupation of East Texas by European colonists. The current research proposes using ceramic attributes to refine decorative elements within types, potentially leading to the identification of Hasinai groups. Ceramic assemblages dominate most Caddo collections and provide the best opportunity to identify groups of the Hasinai Caddo in the archaeological record. Database functionality and spatial analysis of GIS software will facilitate mapping ceramics sherd and vessel attributes, the distribution of European trade goods, and other temporally sensitive artifacts (e.g., projectile point types and knives).

The identification of archaeological sites associated with historically known members of the Hasinai confederacy will greatly contribute to further archaeological research in this area. This study will serve as an example of how archaeologists utilizing curated and unpublished collections, previous research, ethnographic accounts, and technological innovations such as GIS can arrive at new understandings of Native American groups.

Tables 3 and 4 include examples of sorted queries from a database I created in order to manage site and artifact information for this study. Some fields contain reported counts, (i.e., VESSEL COU, T_SHERDS), and some fields are noted as present (1) or absent (0), (i.e., VESSELs, TRADE_BEAD, PP_K). Figure 4 is a map of sites across East Texas where European trade goods have been reported. 
Table 3. Examples of database fields and values collected for analysis.

\begin{tabular}{|c|c|c|c|c|c|}
\hline SITE TRINO & VESSELS & VESSEL_COU & T SHERDs & TRADE BEAD & PP_K \\
\hline 41 NA27 & 1 & 16 & 31615 & 1 & 0 \\
\hline 41RK200 & 0 & 0 & 8548 & 1 & 0 \\
\hline 41SA25 & 0 & 0 & 1579 & 1 & 0 \\
\hline 41SA95 & 0 & 0 & 967 & 0 & 0 \\
\hline 41 NA67 & 0 & 0 & 583 & 1 & 0 \\
\hline 41CE293 & 0 & 0 & 400 & 0 & 0 \\
\hline 41RK191 & 0 & 0 & 360 & 0 & 0 \\
\hline $41 \mathrm{AN} 32$ & 1 & 21 & 341 & 1 & 1 \\
\hline 41CE20 & 1 & 1 & 251 & 1 & 0 \\
\hline 41AG22 & 0 & 0 & 249 & 1 & 1 \\
\hline $41 \mathrm{HO} 214$ & 0 & 0 & 227 & 1 & 0 \\
\hline 41RK197 & 0 & 0 & 199 & 0 & 0 \\
\hline 41AN21 & 1 & 1 & 189 & 0 & 1 \\
\hline $41 \mathrm{HE} 139$ & 0 & 0 & 182 & 0 & 0 \\
\hline $41 \mathrm{AN} 8$ & 1 & 5 & 166 & 0 & 1 \\
\hline 41CE62 & 0 & 0 & 133 & 0 & 0 \\
\hline $41 \mathrm{HO} 211$ & 0 & 0 & 94 & 1 & 0 \\
\hline $41 \mathrm{AN} 26$ & 1 & 30 & 93 & 1 & 1 \\
\hline 41CE354 & 0 & 0 & 90 & 0 & 0 \\
\hline $41 \mathrm{AN} 34$ & 1 & 21 & 68 & 0 & 1 \\
\hline $41 \mathrm{NA} 60$ & 0 & 0 & 44 & 1 & 0 \\
\hline 41HE14 & 0 & 0 & 25 & 0 & 0 \\
\hline $41 \mathrm{NA} 113$ & 1 & 2 & 22 & 1 & 0 \\
\hline 41AN164 & 0 & 0 & 11 & 0 & 0 \\
\hline 41NA139 & 0 & 0 & 10 & 0 & 0 \\
\hline $41 \mathrm{SA} 38$ & 0 & 0 & 5 & 0 & 0 \\
\hline 41AG39 & 0 & 0 & 2 & 1 & 0 \\
\hline $41 \mathrm{CE} 12$ & 1 & 62 & 0 & 1 & 0 \\
\hline 41AN13 & 1 & 17 & 0 & 1 & 1 \\
\hline
\end{tabular}


Table 4. Examples of database fields and values collected for analysis.

\begin{tabular}{|c|c|c|c|c|c|c|}
\hline Phase & Sherd If & Site Tri & Provenience & Sherd & Temper & Decoration \\
\hline Allen & 206 & $41 \mathrm{HO} 214$ & Unit $7,0-10 \mathrm{~cm}$ & body & bone & parallel brushed \\
\hline Allen & 207 & $41 \mathrm{HO} 214$ & Unit $7,0-10 \mathrm{~cm}$ & body & grog & parallel brushed \\
\hline Allen & 208 & $41 \mathrm{HO} 214$ & Unit $7,0-10 \mathrm{~cm}$ & body & grog & deep parallel incised lines \\
\hline Allen & 209 & $41 \mathrm{HO} 214$ & Unit $7,0-10 \mathrm{~cm}$ & body & grog & opposed brushed \\
\hline Allen & 210 & $41 \mathrm{HO} 214$ & Unit $7,0-10 \mathrm{~cm}$ & body & grog & parallel brushed \\
\hline Allen & 211 & $41 \mathrm{HO} 214$ & Unit 7, 0-10 cm & body & grog & parallel incised lines \\
\hline Allen & 212 & $41 \mathrm{HO} 214$ & Unit $7,10-20 \mathrm{c}$ & body & grog/SP & plain \\
\hline Allen & 213 & $41 \mathrm{HO} 214$ & Unit 7, 10-20 c & body & bone & parallel brushed-incised \\
\hline Allen & 214 & $41 \mathrm{HO} 214$ & Unit $7,10-20 \mathrm{c}$ & body & grog & parallel brushed \\
\hline Allen & 215 & $41 \mathrm{HO} 214$ & Unit 7, 10-20 c & body & grog-bone & tool punctated row \\
\hline Allen & 216 & $41 \mathrm{HO} 214$ & Unit $7,10-20 \mathrm{c}$ & body & bone-ht & parallel brushed \\
\hline Allen & 217 & $41 \mathrm{HO} 214$ & Unit $7,10-20 \mathrm{c}$ & body & bone-ht & parallel brushed \\
\hline Allen & 218 & $41 \mathrm{HO} 214$ & Unit $7,20-30 \mathrm{~cd}$ & body & grog & parallel incised, closely-spaced \\
\hline Allen & 219 & $41 \mathrm{HO} 214$ & Unit 7,20-30 c & body & grog & tool punctated rows \\
\hline Allen & 220 & $41 \mathrm{HO} 214$ & Unit $7,20-30 \mathrm{c}$ & body & grog & parallel brushed \\
\hline Allen & 221 & $41 \mathrm{HO} 214$ & Unit $7,20-30 \mathrm{c}$ & body & grog-ht/SP & parallel brushed-incised \\
\hline Allen & 222 & $41 \mathrm{HO} 214$ & Unit $7,20-30 \mathrm{c}$ & body & bone-grog & parallel brushed \\
\hline Allen & 223 & $41 \mathrm{HO} 214$ & Unit $8,0-10 \mathrm{~cm}$ & body & grog-ht & parallel brushed \\
\hline Allen & 224 & $41 \mathrm{HO} 214$ & Unit $8,0-10 \mathrm{~cm}$ & body & bone & neck banded \\
\hline Allen & 225 & $41 \mathrm{HO} 214$ & Unit $8,10-20 \mathrm{c}$ & body & grog & parallel brushed \\
\hline Allen & 226 & $41 \mathrm{HO} 214$ & Unit $8,10-20 \mathrm{c}$ & body & grog-bone & parallel brushed-incised \\
\hline Allen & 227 & $41 \mathrm{HO} 214$ & Unit $8,10-20 \mathrm{c}$ & body & grog & plain \\
\hline Allen & 331 & 41RK191 & RK1 & rim & & incised \\
\hline Allen & 332 & 41RK191 & RK1 & body & & parallel brushed incised \\
\hline Allen & 333 & 41RK191 & RK1 & body & & parallel incised \\
\hline Allen & 334 & 41RK191 & RK1 & body & & parallel incised \\
\hline Allen & 335 & 41RK191 & RK1 & body & & parallel incised \\
\hline Allen & 336 & 41RK191 & RK1 & body & & parallel incised \\
\hline Allen & 337 & 41RK191 & RK1 & body & & parallel incised \\
\hline Allen & 338 & 41RK191 & RK1 & body & & parallel incised \\
\hline Allen & 339 & 41RK191 & RK1 & body & & parallel incised \\
\hline Allen & 340 & 41RK191 & RK1 & body & & parallel incised \\
\hline Allen & 341 & 41RK191 & RK1 & body & & parallel incised \\
\hline Allen & 342 & 41RK191 & RK1 & body & & parallel incised \\
\hline Allen & 343 & 41RK191 & RK1 & body & & parallel incised \\
\hline Allen & 344 & 41RK191 & RK1 & body & & parallel incised \\
\hline Allen & 345 & 41RK191 & RK1 & body & & parallel incised \\
\hline Allen & 346 & 41RK191 & RK1 & body & & crosshatched-incised \\
\hline Allen & 347 & 41RK191 & RK1 & body & & single straight line incised \\
\hline Allen & 348 & 41RK191 & RK1 & body & & single straight engraved line \\
\hline Allen & 349 & 41RK191 & RK1 & body & & single straight engraved line \\
\hline Allen & 350 & 41RK191 & RK1 & body & & parallel engraved \\
\hline Allen & 351 & 41RK191 & RK1 & body & & parallel engraved \\
\hline Allen & 352 & 41RK191 & RK1 & body & & curvilinear engraved \\
\hline Allen & 353 & 41RK191 & RK1 & body & & patton engraved \\
\hline Allen & 354 & 41RK191 & RK1 & body & & patton engraved \\
\hline Allen & 355 & 41RK191 & RK1 & body & & patton engraved \\
\hline Allen & 356 & 41RK191 & RK1 & body & & patton engraved \\
\hline Allen & 357 & 41RK191 & RK1 & rim & & horizontal engraved \\
\hline
\end{tabular}




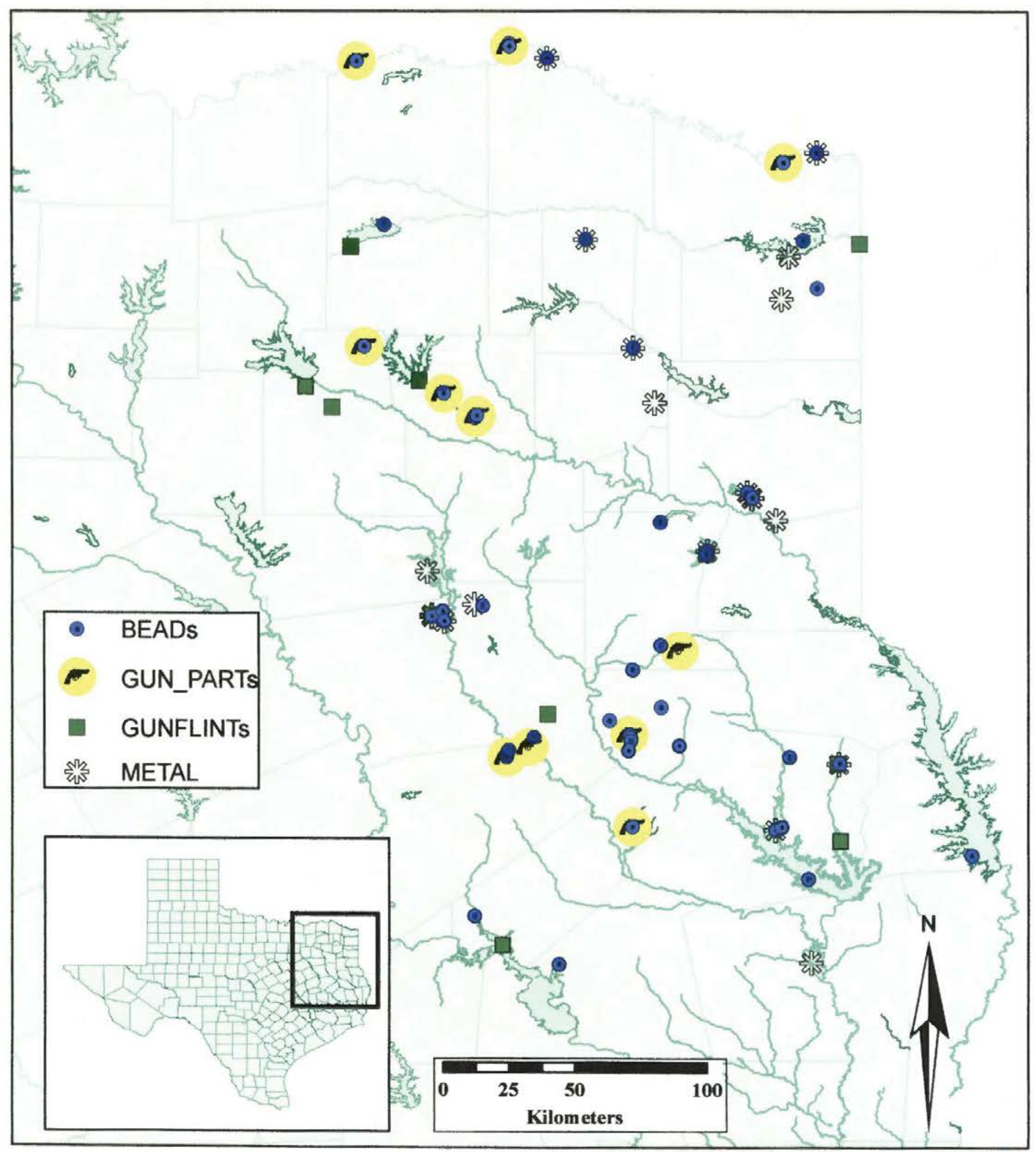

Figure 4. European trade goods reported at sites in East Texas. 


\section{References Cited}

Bolton, H. E.

1987 The Hasinais: Southern Caddoans as seen by the Earliest Europeans. University of Oklahoma Press, Norman.

Campbell, T.N.

1936 A Study of Ornamentation in the Pottery of Prehistoric East Texas, with Special Attention Given to Designs. Master's thesis, Department of Anthropology, The University of Texas at Austin.

Carlson, S. B. and J. E. Corbin

1999 Mission Dolores Revisited. Bulletin of the Texas Archeological Society 70:49-57.

Casañas, Fray Francisco [1691]

1927 Descriptions of the Tejas or Asinai Indians, 1691-1722. Part I \& II. Translated by Mattie Austin Hatcher. Southwestern Historical Quarterly 30:206-218 and 283304.

Cole, N. M.

1975 Early Historic Caddoan Mortuary Practices in the Upper Neches Drainage, East Texas. Master's thesis, Department of Anthropology, The University of Texas at Austin.

Corbin, J. E.

1989 Spanish-Indian Interaction on the Eastern Frontier of Texas. In Columbian Consequences, Vol. 1, Archaeological and Historical Perspectives on the Spanish Borderlands West, edited by D. H. Thomas, pp. 269-276. Smithsonian Institution Press, Washington D.C.

Corbin, J. E., T. C. Alex, and A. Karlina

1980 Mission Dolores de los Ais. Papers in Anthropology No.2. Stephen F. Austin State University, Nacogdoches.

Corbin, J. E., H. A Brown, M. G. Canavan, and S. Toups

1990 Mission Dolores de los Ais (41SA25): San Augustine County, Texas. Archeological Investigations. Stephen F. Austin State University, Nacogdoches.

Erickson, E. C. and J. E. Corbin

1996 Archaeological Survey and Cultural Resource Assessment of Mission Tejas State Historical Park, Houston County, Texas. Texas Parks and Wildlife Department, Austin. 
Espinosa, Fray Isidro Felix de

1927 Descriptions of the Tejas or Asinai Indians, 1691-1722. Part IV. Translated by Mattie Austin Hatcher. Southwestern Historical Quarterly 31:150-180.

Fields, R. C.

1981 Analysis of the Native Made Ceramics from the Deshazo Site, Nacogdoches County, Texas. Master's thesis, Department of Anthropology, The University of Texas at Austin.

Foster, W. C. (editor)

1998 The La Salle Expedition to Texas: The Joumal of Henri Joutel, 1684-1687. Texas State Historical Association, Austin.

Gilmore, K.

1973 Caddoan Interaction in the Neches Valley, Texas. Ph.D. Dissertation, Department of Anthropology, Southern Methodist University, Dallas.

Griffith, W. J.

1954 The Hasinai Indians of East Texas as Seen by Europeans, 1687-1772.

Philological and Documentary Studies, Vol. 2, No. 3. Middle American Research Institute, Tulane University, New Orleans.

Hidalgo, Fray Francisco

1927 Descriptions of the Tejas or Asinai Indians, 1691-1722. Southwestern Historical Quarterly 31 Part III:50-62.

Jelks, E. B.

1965 The Archeology of McGee Bend Reservoir, Texas. Ph.D. dissertation, Department of Anthropology, The University of Texas at Austin.

Joutel, $\mathrm{H}$.

1906 [1713] A Historical Journal of the Late Monsieur de LaSalle's Last Voyage into North America to Discover the River Mississippi. Edited by H.R. Stiles. Joseph McDonough, New York.

Kenmotsu, N. A.

1992 The Mayhew Site: A Possible Hasinai Farmstead, Nacogdoches County, Texas. Bulletin of the Texas Archeological Society 63:135-174.

Kenmotsu, N. A. and T. K. Perttula (editors)

1993 Archeology in the Eastern Planning Region, Texas: A Planning Document. Cultural Resource Management Report 3. Department of Antiquities Protection, Texas Historical Commission, Austin. 
Kleinschmidt, U.K.W.

1982 Review and Analysis of the A.C. Saunders Site, 41AN19, Anderson County, Texas. Master's thesis, Department of Anthropology, The University of Texas at Austin.

Krieger, A. D.

1946 Culture Complexes and Chronology in Northerm Texas, with Extensions of Puebloan Datings to the Mississippi Valley. Publication No. 4640. The University of Texas at Austin.

Margry, P.

1879 Decouvertes et etablissements des Francais dans l'ouest el dans le sud de l'Amerique Septentrionale, 1614-1754. 6 vols. Paris.

Newell, H. P. and A. D. Krieger

1949 The George C. Davis Site, Cherokee County, Texas. Memoirs No. 5. Society for American Archaeology, Menasha, Wisconsin.

Perttula, T. K.

1992 "The Caddo Nation": Archaeological and Ethnohistoric Perspectives. University of Texas Press, Austin.

1993 Kee-Oh-Na-Wah'-Wah: The Effects of European Contact on the Caddoan Indians of Texas, Louisiana, Arkansas and Oklahoma. In Ethnohistory and Archaeology: Approaches to Postconlact Change in the Americas, edited by J. D. Rogers and S. M. Wilson, pp. 89-109. Plenum Press, New York.

2001 "The Great Kingdom of the Tejas": The Life and Times of Caddo Peoples in Texas between ca. 1530-1859. Bulletin of the Texas Archeological Society 72:7389.

$200541 \mathrm{HO} 64 / 41 \mathrm{HO} 65$, Late 17th to Early 18th Century Caddo Sites on San Pedro Creek in Houston County, Texas. Bulletin of the Texas Archeological Society 75:85-103.

Perttula, T. K. and B. Nelson

2006 Test Excavation at Three Caddo Sites at Mission Tejas State Park, Houston County, Texas. Report of Investigations No. 76. Archeological \& Environmental Consultants, LLC, Austin.

Shafer, H. J.

n.d Toward an Application of the Modified Wheat-Gifford-Wasley Taxonomy to Fulton Aspect, Frankston and Allen Focus Pottery. Report on file, Texas Archeological Research Laboratory, The University of Texas at Austin. 
Stephenson, R. L.

1948 Archeological Survey of McGee Bend Reservoir: A Preliminary Report. Bulletin of the Texas Archeological and Paleontological Society 19:57-73.

Story, D. A.

1990 Cultural History of the Native Americans. In The Archeology and Bioarcheology of the Gulf Coastal Plain, by D. A. Story, J. A. Guy, B. A. Burnett, M. D. Freeman, J. C. Rose, D. G. Steele, B. W. Olive, and K. J. Reinhard, pp. 163-366. Research Series No. 38. 2 Vols. Arkansas Archeological Survey, Fayetteville.

Story, D. A. (editor)

1982 The Deshazo Sile, Nacogdoches County, Texas, Volume 1: The Site, Its Setting, Investigations, Cultural Features, Artifacts of Non-Native Manufacture, and Subsistence Remains. Texas Antiquities Permit Series No. 7. Texas Antiquities Committee, Austin.

1995 The Deshazo Site, Nacogdoches County, Texas, Volume 2: Artifacts of Native Manufacture. Studies in Archeology 21. Texas Archeological Research Laboratory, The University of Texas at Austin.

Story, D. A. and D. G. Creel

1982 The Cultural Setting. In The Deshazo Sile, Nacogdoches County, Texas, Volume 1: The Site, Its Setting, Investigations, Cultural Features, Artifacts of Non-Native Manufacture, and Subsistence Remains, edited by D. A. Story, pp. 20-34. Texas Antiquities Permit Series No. 7. Texas Antiquities Committee, Austin.

Suhm, D. A., A. D. Krieger, and E. B. Jelks

1954 An Introductory Handbook of Texas Archeology. Bulletin of the Texas Archeological and Paleontological Society 25 (whole volume).

Suhm, D. A. and E. B. Jelks (editors)

1962 Handbook of Texas Archeology: Type Descriptions. Special Publication No. 1, Texas Archeological Society, and Bulletin No. 4, Texas Memorial Museum, Austin.

Tous, G. (translator)

1930 Ramon's Expedition: Espinosa's Diary of 1716. Preliminary Studies of the Texas Catholic Historical Society I(4):1-24 (April).

Wyckoff, D. G. and T. G. Baugh

1980 Early Historic Hasinai Elites: A Model for the Material Culture of Governing Elites. Mid-Continental Journal of Archaeology 5:225-283. 